\title{
Keterampilan Guru SD dalam Menghadapi Era Revolusi Industri 4.0
}

\section{Dede Salim Nahdi, Ujiati Cahyaningsih}

Universitas Majalengka

salimnahdi@unma.ac.id

\section{Article History}

accepted 24/09/2019

\begin{abstract}
One of the great challenges of Indonesian society in the era of the industrial revolution 4.0 is globalization, where globalization can lead to greater competition in all areas of people's lives, including education. The teacher as the spearhead of education is the most important element in an education system. Student learning processes are strongly influenced by teacher competence. Teachers have a strategic role in the field of education, even other sources of adequate education are often meaningless if not supported by the presence of qualified teachers. The basic ability to read, write and count absolutely is no longer enough to be able to compete in the era of the industrial revolution 4.0 which is full of challenges. Education must be able to prepare students to compete in the global community. For this reason, teachers must be able to adapt to all forms of change. In the era of the industrial revolution 4.0, where all educational activities and even the joints of life are inseparable from the use of digital technology, teachers must have some skills to deal with cultural change in this fast-paced era.

Keywords: Primary School Teacher Skills, Industrial Revolution Era 4.0
\end{abstract}

\begin{abstract}
Abstrak
Masuknya era revolusi industri 4.0 memberikan tantangan yang sangat besar bagi masyarakat Indonesia. Salah satu tantangan tersebut adalah globalisasi. Globalisasi menjadikan persaingan di segala bidang kehidupan masyarakat menjadi semakin besar, termasuk bidang pendidikan. Guru sebagai garda terdepan di bidang pendidikan memiliki peran utama dalam berhasilnya sebuah sistem pendidikan, karena kegiatan pembelajaran yang diikuti siswa sangat dipengaruhi oleh kompetensi guru. Guru memiliki peran yang sangat strategis di bidang pendidikan, bahkan sumber referensi lain yang dianggap memadai sering kali menjadi tidak berarti apabila tidak didukung adanya seorang guru berkualitas. Kemampuan dasar siswa seperti membaca, menulis, dan berhitung mutlak tidak lagi cukup untuk dapat bersaing di era revolusi industri 4.0 dengan segala tantangannya. Oleh karena itu, pendidikan yang dilaksanakan harus menyiapkan siswa agar mampu bersaing di masyarakat global. Untuk itulah guru harus mampu beradaptasi dengan segala bentuk perubahan yang terjadi. Pada era ini, guru harus memiliki keterampilan yang dibutuhkan untuk menghadapi perubahan yang serba cepat ini.
\end{abstract}

Kata kunci: Keterampilan Guru SD, Era Revolusi Industri 4.0.

Social, Humanities, and Education Studies (SHEs): Conference Series https://jurnal.uns.ac.id/shes 


\section{PENDAHULUAN}

Revolusi industri 4.0 merupakan era yang lahirnya teknologi digital yang berdampak sangat masif terhadap setiap dimensi kehidupan manusia. Proses otomatisasi pada semua aktivitas manusia melahirkan banyak perubahan dan perkembangan yang begitu pesat sehingga merubah berbagai aspek kehidupan secara fundamental. Revolusi industri generasi ke-4 ini memiliki ruang lingkup, dimensi, dan kompleksitas yang sangat luas. Teknologi yang mengintegrasikan aspek fisik, digital dan biologis telah memberikan pengaruh yang cukup besar terhadap bidang ilmu, ekonomi, industri, kesehatan, dan bahkan pendidikan. Pesatnya ilmu pengetahuan dan teknologi pada era ini telah memberikan konsekuensi terhadap besarnya tantangan yang berbeda dari sebelumnya. Banyak hal yang akhirnya berubah di era revolusi industri 4.0, pesatnya perkembangan di bidang ilmu pengetahuan dan teknologi serta sistem informasi dan komunikasi seperti akses internet yang cepat menjadi salah satu tanda datangnya era revolusi industri 4.0. Pada era ini dunia seakan-akan berada dalam genggaman tangan karena setiap kejadian di ujung dunia sana, akan dengan cepat diketahui di ujung dunia yang lain dalam waktu yang hampir bersamaan. Karakteristik era revolusi industri 4.0 ditandai dengan semakin bertautnya dunia ilmu pengetahuan, sehingga sinergi diantara keduanya menjadi semakin cepat.

Menyikapi tantangan era revolusi industri 4.0, maka bidang pendidikan tidak bisa mengabaikan begitu saja perubahan ini. Pendidikan harus mampu beradaptasi terhadap segala perubahan. Pendidikan harus harus mampu menyiapkan sumber daya manusia yang kompetitif sehingga pendidikan di Indonesia menjadi lebih berkualitas dan berjalan sesuai dengan tujuan yang diharapkan. Melihat kualitas pendidikan di Indonesia dewasa ini, nampaknya tujuan yang diharapkan belum sepenuhnya terwujud. Jika merujuk beberapa hasil studi maka kualitas pendidikan di Indonesia masih belum maksimal. Dalam sebuah laporan mengenai Human Development Report 2016 yang dikeluarkan oleh Badan Program Pembangunan di bawah PBB (United Nations Development Programme/UNDP), terungkap fakta bahwa Indeks Pembangunan Manusia (IPM) Indonesia pada tahun 2017 hanya sebesar 70,81 sehingga berada di tingkat 113 dari total sebanyak 188 negara di dunia, turun dari peringkat 110 pada tahun 2014. Selain itu, sebuah studi Education For All (EFA) Global Monitoring Report 2011: "The Hidden Crisis, Armed Conflict and Education" yang dilakukan oleh UNESCO mengungkapkan bahwa Indeks Pembangunan Pendidikan Indonesia pada tahun 2011 menurun dari peringkat 65 ke peringkat 69 dari 127 negara, (Majid, 2014). Dari kedua data hasil studi tersebut diperoleh gambaran jelas mengenai masih rendahnya kulitas pendidikan di Indonesia. Akibatnya, daya saing bangsa Indonesia sangat rendah. Hal ini terlihat hasil survey, dari 57 negara di dunia Indonesia hanya menduduki urutan ke-37 (The World Economic Forum Swedia Report, 2000). Predikat Indonesia pun hanya sebagai follower dan bukan sebagai leader teknologi dari 53 negara peserta di dunia. Dari fakta yang dipaparkan di atas, maka diperlukan langkah-langkah strategis untuk meningkatkan kualitas pendidikan di Indonesia. Semua stakeholder pendidikan harus berkontribusi untuk kemajuan pendidikan Indonesia sesuai dengan peran, tugas, fungsi dan kapasitasnya. Guru sebagai unsur yang bersentuhan langsung dengan siswa harus mampu menjadi agen perubahan yang dapat menyiapkan siswanya menjadi generasi penerus eksistensi bangsa, sehingga pendidikan mampu melahirkan generasi yang siap menghadapi berbagai tantangan yang muncul di masa yang akan datang.

Merupakan cita-cita setiap bangsa untuk menjadikan seluruh rakyatnya dapat hidup bahagia dan sejahtera, hidup sejajar serta dihormati oleh bangsa-bangsa lain. Demikian pula bangsa Indonesia bercita-cita untuk tumbuh dan berkembang untuk kesejahteraan dan kebahagiaan rakyatnya, hidup berdampingan dengan bangsa lain, duduk sama rendah dan berdiri sama tinggi serta dihormati bangsa-bangsa lain di 
dunia global. Cita-cita ini dapat dan harus diraih dengan kemampuan sendiri, dan hanya dapat diwujudkan melalui pendidikan bagi seluruh anak bangsa.

Guru sebagai garda terdepan di bidang pendidikan, harus terus melakukan pengembangan diri secara berkelanjutan agar menjadi guru yang mampu menghasilkan sumber daya manusia yang berkualitas. Guru harus mengubah perspektif tentang pendidikan agar dapat beradaptasi dengan teknologi baru dan siap menghadapi tantangan global. Perubahan yang dilakukan tentu tidak cukup hanya sekadar metode mengajar, tetapi jauh yang lebih penting adalah guru harus mengubah perspektif terhadap konsep pendidikannya tentang bagaimana menyiapkan anak didiknya menghadapi persaingan era revolusi industri 4.0. Dalam era revolusi industri 4.0, pendidikan setidaknya harus mampu menyiapkan peserta didiknya menghadapi tiga hal berikut: 1) pendidikan harus menyiapkan anak agar mampu bekerja untuk pekerjaannya saat ini belum ada; 2) pendidikan harus menyiapkan anak untuk dapat menyelesaikan permasalahan yang masalahnya saat ini belum muncul, dan 3) pendidikan harus menyiapkan anak untuk dapat menggunakan teknologi yang pada saat ini teknologinya belum ditemukan. Sungguh sebuah tugas yang tidak mudah bagi dunia pendidikan, khususnya para guru. Untuk bisa menghadapi tantangan tersebut, syarat utama yang harus dimiliki yaitu bagaimana menyiapkan guru yang memiliki kualitas dalam kualifikasi dan kompetensinya (Baihaqi, 2019).

\section{Pendidikan di Era revolusi industri 4.0}

\section{HASIL DAN PEMBAHASAN}

Era revolusi industri 4.0 menjadi tantangan sangat berat bagi guru Indonesia. Mengutip pendapat Jack Ma dalam kegiatan World Economic Forum 2018, jika guru tidak mengubah metode mengajar, maka 30 tahun mendatang kita akan mengalami kesulitan yang sangat besar. Pendidikan adalah wilayah yang dipandang paling bertanggung jawab untuk mempersiapkan generasi muda menghadapi masa depannya, bagaimanapun bentuknya. Di masa yang akan datang, persaingan menjadikan hidup menjadi tidak mudah akibat dari tantangan global. Namun, di balik maraknya perdebatan mengenai abad ke-21 yang seringkali disebut dengan era revolusi industri 4.0, guru perlu menyiapkan pendidikan dan pembelajaran yang tidak hanya penuh dengan muatan pengetahuan. Pendidikan yang dilaksanakan jangan mengesampingkan muatan sikap dan keterampilan sebagaimana saat ini terjadi karena hal itu akan melahirkan anak didik yang tidak mampu bersaing dengan mesin. Transfer pengetahuan yang dominan dalam pendidikan dan pembelajaran harus diubah agar kelak generasi muda Indonesia mampu bersaing serta mampu bersikap bijak dalam menggunakan mesin untuk kemaslahatan. Dalam pembelajaran, guru harus menanamkan nilai-nilai karakter kepada anak didiknya, termasuk dalam memanfaatkan kemajuan teknologi informasi secara bijak serta sebagai sumber inspirasi bagi anak didiknya.

Pendidikan dasar merupakan peletak pondasi dasar bagi anak-anak dalam mempersiapkan diri untuk melanjutkan pendidikan ke jenjang yang lebih tinggi, dan labih jauh lagi untuk menghadapi tantangan yang akan mereka hadapi di masa yang akan datang. Keberhasilan seseorang dalam menghadapi tantangan hidup, sangat tergantung pada pendidikan yang ditempuh sejak pendidikan dasar. Keberhasilan menempuh pendidikan dasar akan berdampak besar terhadap keberhasilan pendidikan berikutnya. Jika seorang anak mengalami kesulitan pada saat menempuh pendidikan menengah atau tinggi, maka bisa jadi anak tersebut tidak benar-benar memiliki pondasi yang kuat saat menempuh pendidikan dasar. Menjadi tugas sangat berat yang harus diemban seorang guru SD untuk mengantar anak didiknya meraih tujuan-tujuan yang diharapkan. Karena itulah, guru SD diharuskan untuk terus mengembangkan dirinya agar memiliki keterampilan yang dibutuhkan dalam menghadapi era revolusi industri 4.0. 


\section{Keterampilan Guru SD di Era Revolusi Industri 4.0}

Revolusi industri 4.0 telah membawa perubahan pada setiap dimensi kehidupan. Salah satu perubahan tersebut adalah aktivitas sehari-hari dan produktivitas manusia yang semakin berkurang karena perannya mulai tergantikan oleh mesin. Dampaknya, peran manusia mulai tereduksi dalam berbagai aspek kehidupan. Sebagai contoh, kemunculan onlineshop (toko online) yang menggunakan sistem perdagangan digital dewasa ini telah menggerus eksistensi pedagang tradisional. Saat ini, orang lebih memilih melakukan transaksi jual beli secara online yang memberikan kemudahan karena dapat dilakukan di mana saja dan kapan saja. Beberapa kegiatan industri yang mengandalkan tenaga manusia juga telah tergantikan oleh tenaga robotik. Dalam lima tahun yang akan datang, diprediksi akan menghilangkan lebih dari 35\% jenis pekerjaan manusia, dan dalam sepuluh tahun kemudian akan menghilangkan hampir $75 \%$ jenis pekerjaan, karena perannya digantikan oleh teknologi digitalisasi program. Demikian halnya pada dunia pendidikan, mungkin saja pada saatnya peran guru sebagai transformator dan fasilitator pengetahuan kepada anak didiknya akan terreduksi, karena konten pengetahuan dan simulasi peraga pembelajaran akan tersedia dalam bentuk digitalisasi program. Menyikapi tantangan era revolusi industri 4.0, maka guru tidak bisa mengabaikan perubahan ini. Sebaik apapun sistem dan kurikulum yang disusun dan ditetapkan, tidak akan ada manfaaatnya ketika guru tidak mampu dan mau berubah mengikuti tuntutan perkembangan yang ada. Maka dibutuhkan kesiapan guru dalam mengikuti arus perubahan yang terjadi begitu cepat dari waktu ke waktu. Guru dituntut untuk cepat beradaptasi dengan perkembangan dunia. Guru dituntut untuk terus mengembangkan diri agar memiliki keterampilan yang dibutuhkan untuk menghadapi perubahan yang terjadi di era revolusi industri 4.0. Menurut Frydenberg \& Andone (Nahdi, 2019) untuk menghadapi era revolusi industri 4.0, setiap orang harus memiliki beberapa keterampilan di antaranya berpikir kritis, pengetahuan dan kemampuan literasi digital, serta terampil dalam memanfaatkan teknologi informasi dan komunikasi dengan baik. Dengan demikian, dalam menghadapi era revolusi industri 4.0 setidak guru harus memiliki keterampilan berpikir kreatif, berpikir kritis, dan literasi digital.

a. Berpikir Kreatif

Menurut Kamus Besar Bahasa Indonesia (KBBI) kreatif berarti memiliki daya cipta atau kemampuan untuk menciptakan, suatu kemampuan untuk melahirkan hal yang baru, baik berupa ide atau gagasan maupun kenyataan yang relatif berbeda dengan sebelumnya. Ada pun berpikir kreatif adalah sebuah proses berpikir yang melibatkan unsur-unsur keaslian, kelancaran, keluwesan, dan elaborasi. Berpikir kreatif dapat mengembangkan daya pikir yang meliputi wawasan dengan komponenkomponen yang luas (Susanto, 2013:110). Orang yang memiliki kemampuan berpikir kreatif dapat mengembangkan suatu gagasan baru yang berkualitas (Sani, 2014:15).

Tujuan paling penting dari pendidikan saat ini adalah melatih individu yang positif, kreatif dan efisien, yang dapat menyesuaikan diri dengan kondisi yang berbeda, serta mampu berpikir fleksibel terbuka, bebas dan ilmiah (Bulut, 2019). Perkembangan teknologi telah menuntut semua orang untuk mampu menyesuaikan diri, termasuk seorang guru yang tugas melaksanakan pembelajaran bagi para anak didiknya. Guru sulit bersaing dengan mesin yang mampu melakukan pencarian informasi dan pengetahuan secara cepat dan efektif. Atas dasar itulah pada era revolusi industri 4.0, guru dituntut untuk mampu berpikir kreatif dalam merencanakan pembelajaran di kelas. Kreativitas seorang guru mutlak dibutuhkan untuk dapat mengubah situasi pembelajaran menjadi menarik dan efektif sesuai dengan perkembangan jaman. Jika di era revolusi industri 4.0 teknologi digital mempengaruhi aktivitas kehidupan, maka guru harus mampu menciptakan gagasan baru untuk merancang kegiatan pembelajaran dengan menggunakan teknologi digital. Jika sebelumnya kegiatan 
pembelajaran masih bersifat tradisional, maka guru harus mengubah cara mengajar menjadi pembelajaran multi-stimulan agar lebih menyenangkan dan menarik bagi siswa. Kreativitas guru dalam memanfaatkan teknologi informasi mutlak dibutuhkan sebagai bagian yang tidak terpisahkan dalam kegiatan pembelajaran. Siswa akan lebih termotivasi jika pembelajaran yang dilaksanakan memanfaatkan teknologi. Karenanya, dibutuhkan guru yang mampu menempatkan posisinya dengan tepat dan mampu mengoptimalkan perannya sebagai guru masa depan yang indentik dengan guru kreatif. Dengan guru kreatif inilah maka akan terlahir pula siswa yang inovatif.

b. Berpikir Kritis

Berpikir kritis adalah cara berpikir logis dan reflektif yang dipusatkan pada keputusan mengenai sesuatu yang harus diraih atau sesuatu yang harus dilaksanakan (Gane, 1980). Berpikir kritis adalah jenis pemikiran yang didasarkan pada individu yang mempertanyakan proses berpikir dirinya dan orang lain dalam memahami dunianya sendiri (Coskun dan Altinkurt, 2016). Sesorang yang mampu berpikir kritis akan mampu menganalisis atau mengevaluasi informasi yang diterima maupun masalah yang dihadapi, serta memiliki keinginan atau motivasi untuk menemukan jawaban dan pemahaman atas informasi atau masalah tersebut. Dengan berpikir kritis, maka kita dapat menelaah proses berpikir orang lain untuk mengetahui logika berpikir yang digunakan. Seseorang yang mampu berpikir kritis cenderung akan mencari kebenaran dan berpikir divergen sehingga terbuka dan toleran terhadap gagasan-gagasan baru. Di samping itu dengan berpikir kritis dapat menjadikan kita mampu menganalisis masalah dengan baik, mampu berpikir secara sistematis, penuh rasa ingin tahu, dewasa dalam berpikir, dan dapat berpikir secara mandiri (Nahdi, 2015: 14). Melalui kemampuan berpikir kritis, seseorang akan mampu menemukan analogi dan hubungan antara bagian-bagian informasi yang terpisah, mampu menentukan keseuaian dan keabsahan informasi yang digunakan untuk menyusun dan menyelesaikan masalah, serta mampu menemukan dan mengevaluasi solusi atau alternatif dalam mengatasi masalah yang dihadapi (Potts, 2004).

Berpikir kritis merupakan kemampuan prasyarat yang harus dimiliki guru dalam menghadapi revolusi industri 4.0. Semakin terbukanya informasi yang tersedia di internet menjadikan guru harus mampu kritis dalam menentukan keabsahan dan kebenarannya. Hal ini penting dimiliki guru agar kesalahan informasi yang diperoleh tidak sampai dikonsumsi oleh siswanya. Akan berbahaya jika guru menyampaikan informasi yang salah kepada siswanya. Selama ini siswa masih menganggap guru sebagai sumber informasi yang valid dan benar sehingga sesuatu yang salah akan dianggap benar jika itu keluar dari ucapan gurunya.

c. Literasi Digital

Memasuki era revolusi industri 4.0, guru dan siswa hidup dalam dunia digital yang serba terbuka. Guru dan siswa harus memperoleh keterampilan literasi digital yang memungkinkan mereka memilih dan menggunakan perangkat digital yang sesuai untuk tujuan mereka (Durriyah \& Juhdi, 2018). Dalam kaitan ini, peran dan eksistensi guru menjadi amat penting agar melek pada literasi digital. Literasi digital (digital literacy) merupakan keterampilan menggunakan teknologi dan informasi dari perangkat digital dalam berbagai konteks akademik, karir dan kehidupan sehari-hari secara efektif dan efisien (Gilster, 1997). Melalui kemampuan literasi digital, seseorang akan mampu membuat dan berbagi dalam ragam dan bentuk yang berbeda; mampu bekerjasama, dan melakukan komunikasi lebih efektif, serta dapat memahami menggunakan teknologi digital yang baik dalam mendukung proses tersebut (Hague dan Payton, 2010:2). Dengan kemampuan literasi digital, orang akan mampu memahami informasi secara efektif dan efisien, mampu mengumpulkan, menganalisis dan menyajikan informasi, serta membangun jaringan komunikasi dan menggunakan berbagai aplikasi digital. Karakteristik literasi digital tidak hanya mengacu pada keterampilan dalam mengoperasikan dan menggunakan berbagai perangkat teknologi informasi dan 
komunikasi, tetapi juga untuk proses membaca dan memahami sajian isi perangkat teknologi serta proses menciptakan dan menulis menjadi sebuah pengetahuan baru (Kurnianingsih, 2017). Guru dituntut untuk dapat melaksanakan kegiatan pembelajaran dengan mengintegrasikan berbagai program digital. Digitalisasi yang dapat dilakukan adalah digitalisasi proses pembelajaran, bahan ajar, media pembelajaran, dan evaluasi pembelajaran dengan menggunakan berbagai program aplikasi. Digitalisasi dalam kegiatan pembelajaran ini membutuhkan keterampilan yang terlatih, dan hingga saat cenderung masih menjadi permasalahan bagi sebagian guru.

Di samping itu, seluruh anak didik yang ada di sekolah, termasuk siswa SD, merupakan digital native yang lahir dan tumbuh di era digital. Oleh karena itu, para guru harus mampu secara efektif membimbing dan mendampingi generasi muda yang mereka didik. Dengan literasi digital yang baik, anak akan mudah diarahkan untuk selektif dalam menerima informasi. Pelatihan literasi digital diperlukan agar siswa memiliki sikap kritis dalam menyikapi setiap informasi yang diterima. Siswa perlu diberikan pemahaman berkenaan dengan aturan dalam menggunakan sosial media pada kehidupannya (Silvana dan Cecep, 2018).

\section{SIMPULAN}

Era Revolusi industri 4.0 merupakan hasil inovasi dan kreatifitas manusia serta menjadi bagian dari perkembangan dinamika kehidupan manusia. Sektor pendidikan harus mampu mengimbanginya melalui strategi yang sistematis sesuai dengan dimensi dan orientasi revolusi industri 4.0. Era revolusi industri 4.0 merupakan otomatisasi segala aktifitas yang bersifat akademis dan non akademis. Otomatisasi dengan pemanfaatan teknologi digital menjadikan segala aktivitas semakin disederhanakan namun dapat mereduksi dan bahkan menghilangkan peran manusia. Di samping itu, semakin terbukanya teknologi informasi menjadikan akses ke sumber informasi menjadi lebih mudah dan cepat. Karenanya, untuk menghadapi era tersebut guru perlu memiliki keterampilan berpikir kreatif, berpikir kritis dan literasi digital dalam menghadapi segala tantangan dan perubahan. Keterampilan berpikir kreatif akan menjadikan guru lebih produktif dalam menghasilkan ide dan gagasan baru, keterampilan berpikir kritis akan menjadikan guru lebih selektif dalam menerima informasi yang diperoleh dari media daring, dan literasi digital akan menjadikan guru terampil menggunakan teknologi dan informasi dari piranti digital secara efektif dan efisien dalam tugasnya sebagai pendidik.

\section{DAFTAR PUSTAKA}

Baihaqi. (2019). Ini Lima Kompetensi yang Harus Dimiliki Guru di Era Revolusi Industri 4.0. Kemenag Kalteng. Diakses dari https://kalteng.kemenag.go.id/palangkaraya/berita/501146/Ini-Lima-Kompetensiyang-Harus-Dimiliki-Guru-di-Era-Revolusi-Industri-40.

Bulut, B. (2019). The Impact of Peer Instruction on Academic Achievements and Creative Thinking Skills of College Students. International Journal of Educational Methodology. Volume 5 (3), $503-512$.

Coskun, M. V., \& Altinkurt, Y. (2016). The Relationship between Values and Critical Thinking Dispositions of Pre-Service Teachers. Educational Process: International Journal, 5(4), 298-312.

Durriyah, TL. \& Zuhdi, M. (2018). Digital Literacy With EFL Student Teachers: Exploring Indonesian Student Teachers' Initial Perception About Integrating Digital Technologies Into a Teaching Unit. International Journal of Education \& Literacy Studies. 6 (3). 53-60.

BSNP. (2010). Paradigma Pendidikan Nasional Abad XXI. 
Gane, R. M., Brings, L. J., \& Wager, W. W. (1992). Principles of instructional Design 4th ed. Orlando: Holt Rinehart, and Winston.

Gilster, P. (1997). Digital Literacy. New York: Wiley

Hague, C dan Payton, S. (2010). "Digital Literacy Across the Curriculum: a Futurelab Handbook. United Kingdom" dalam https://www.nfer.ac.uk/publications/FUTL06/FUTL06.pdf, $\quad$ Retrieved 17 September 2019.

Kemdikbud. (n.d.). Jumlah Data Satuan Pendidikan (Sekolah) Per Provinsi. Retrieved 17 September 2019, from http://referensi.data.kemdikbud.go.id/index11.php

Kurnianingsih, dkk. (2017). Upaya Peningkatan Kemampuan Literasi Digital bagi Tenaga Perpustakaan Sekolah dan Guru di Wilayah Jakarta Pusat Melalui Pelatihan Literasi Informasi. Jurnal Pengabdian kepada Masyarakat. Vol. 3 (1). 61-76

Majid, M.S.A. (2014). Analisis Tingkat Pendidikan Dan Kemiskinan Di Aceh. Jurnal Pencerahan. Vol 8 (1). Hal 15- 37.

Nahdi, D.S. (2019). Keterampilan Matematika di Abad 21. Jurnal Cakrawala Pendas. Vol 5 No 2. 133-140.

Nahdi, D. S. (2015). Meningkatkan Kemampuan Berpikir Kritis dan Penalaran Matematis Siswa Melalui Model Brain Based Learning. Jurnal Cakrawala Pendas. (I) hal. 13-22.

Potts, B. (2004). Strategies for Teaching Critical Thinking. Journal of Practical Assesment, Research and Evaluation. 4 (3). 1-3.

Sani. (2014). Pembelajaran saintifik untuk implementasi kurikulum 2013. Jakarta: Bumi Aksara.

Silvana dan Cecep. (2018). Pendidikan Literasi Digital di Kalangan Usia Muda di Kota Bandung. Jurnal Pedagogia. Vol 16 (2). 146-156

Susanto.(2013). Teori Belajar dan Pembelajaran di Sekolah Dasar. Jakarta: PT Fajar Interpratama Mandiri. 